\title{
Climate, Deer and Hogs: Drivers of Rapid Change in a Hickory-Dominated Maritime Forest on St. Catherines Island
}

\author{
C. Ken Smith1, Elise Landreaux¹, Hali Steinmann'1, Royce Hayes², Alastair Keith-Lucas', \\ Christa Hayes ${ }^{2}$ \\ ${ }^{1}$ Forestry and Geology Department, University of the South, Sewanee, Tennessee, USA \\ ${ }^{2}$ St. Catherines Island Foundation, Midway, Georgia, USA \\ Email: ksmith@sewanee.edu
}

Received 26 December 2014; accepted 15 January 2015; published 19 January 2015

Copyright (C) 2015 by authors and Scientific Research Publishing Inc.

This work is licensed under the Creative Commons Attribution International License (CC BY).

http://creativecommons.org/licenses/by/4.0/

(c) (i) Open Access

\section{Abstract}

Maritime forests in the southeastern United States are very susceptible to climate change and have experienced dramatic reductions in extent following anthropogenic disturbances over the past two hundred years. St. Catherines Island, Georgia, an undeveloped barrier island, is home to an unusual pignut hickory (Carya glabra) maritime forest that is experiencing rapid rates of change, including a reduction in basal area from $23 \mathrm{~m}^{2} \cdot \mathrm{ha}^{-1}$ in 1996 to $15 \mathrm{~m}^{2} \cdot \mathrm{ha}^{-1}$ in 2014 . Nine permanent forest plots and associated animal exclosures were installed across this 37 ha stand in 2012 to track forest change and seedling recruitment. From 2012 to 2014, declines in total basal area were caused by mortality of pignut hickory in the overstory and redbay (Persea borbonia) in the midstory. Pignut hickory continues to be ranked first in relative frequency, density and dominance, while Sabal palm (Sabal palmetto) is slightly increasing in relative density. In 2012, there were no woody species regenerating in any of the plots and following one year of animal exclosures, we found 478 pignut hickory seedlings ha-1; thus, deer browse and feral hog predation of nuts may be important drivers of change in this stand. The interplay among deer browse, exotic animal pressures, exotic insects and a drier climate has resulted in a very open forest with the regeneration of few woody plants. Without management of the feral hog and deer population, this unusual maritime forest, with trees as old as 250 years, may continue to decline.

\section{Keywords}

Pignut Hickory, Maritime Forest, Deer Browse, Barrier Island 


\section{Introduction}

In the United States, southeastern maritime forests are among the rarest and least studied coastal biological communities [1]. Salt spray, depth of fresh groundwater and soil salinity largely determine the extent of maritime forests on barrier islands, and on Hog Island, Virginia, Hayden et al. [2] noted that all the island's plant communities experienced rapid rates of change and were susceptible to sea level rise. On Cumberland Island, Georgia, historic human activities, such as conversion of forest to agriculture and pasture, have resulted in longterm changes in patterns of vegetation cover across the island [3]. On Bald Head Island, North Carolina, urban development has forced the deer population to seek browse in the remaining tracts of maritime forest, which authors hypothesized would alter tree regeneration in the coming years [4]. Clearing of forest for agriculture, logging, the introduction of domestic livestock, the lowering of aquifers, and urban development have greatly altered the extent and composition of the remaining maritime forests on southeastern barrier islands [1] [5]-[7].

St. Catherines Island, a privately owned and undeveloped barrier island off the coast of Georgia, is an excellent location to study maritime forest dynamics because of a long standing archeology program which has elucidated much of the 5000 years' worth of human history on the island [8]. In addition, the forests on the island do not face urban development pressures, a common feature of other barrier islands in the region. The island is managed for conservation, education and research; and although the island's forests are exposed to disturbances, they are allowed to recover without human intervention.

The island surface area covers approximately 5700 ha (including salt marsh and beach dunes), and nearly half of the island is an upland core composed of stable Pleistocene sediments that support forest vegetation which is infrequently exposed to storm overwash [9]. The highest elevation on the Pleistocene core is $5 \mathrm{~m}$. In the central part of the island, an upland rise exists that is dominated by pignut hickory (Carya glabra), a species found growing throughout the eastern deciduous forest and occasionally on the southeastern Atlantic barrier islands [10]. This particular hickory-dominated stand was very distinct compared with the surrounding forest, and the Georgia Department of Natural Resources gave it a unique classification as a "dry hickory maritime forest" [11]. A previous study in this stand, which examined hickory dynamics over a 11-year time span in a single 0.6 ha plot, found that no seedlings had moved into a sapling class over the duration of the study, and Evans and Keen [12] speculated that heavy browse pressure by white-tailed deer (Odocoileus virginianus) and seed predation by feral hogs (Sus scrofa) would eventually lead to the demise of this hickory dominated forest.

To better understand the dynamics of this unusual maritime forest that is potentially in decline, we partnered with the island's management team to establish and inventory randomly located permanent plots and animal exclosures throughout this stand. Our primary study objectives were to examine forest recruitment and mortality, temporal changes in plant cover and the density of tree species, and to evaluate tree seedling recruitment inside the animal exclosures.

\section{Methods}

\subsection{Site Description}

St. Catherines Island, Georgia (USA, $31^{\circ} 39^{\prime} \mathrm{N}, 81^{\circ} 09^{\prime} \mathrm{W}$ ) is approximately $13 \mathrm{~km}$ long and $5 \mathrm{~km}$ across at its widest point. It is located $6 \mathrm{~km}$ from the mainland, between Ossabaw Island to the north and Blackbeard-Sapelo Islands to the south. The hickory dominated stand (37 ha in extent) is located on one of the highest points on the stable Pleistocene core (approximately $5 \mathrm{~m}$ elevation). Soils in this stand are deep ( $>3 \mathrm{~m}$ ) and primarily classified as Echaw and Centenary fine sands (Spodosols) with Foxworth fine sands (Entisols) on the edges of the stand [13]. In this region, annual rainfall averages approximately $110 \mathrm{~cm}$ per year [14], and the average annual temperature is approximately $19^{\circ} \mathrm{C}$. An analysis of rainfall data from nearby Sapelo Island indicated that over the past 14 years, St. Catherines has experienced 9 years with below average rainfall, and five of those years were $20 \mathrm{~cm}$ below average rainfall.

\subsection{Sampling Sites}

The island was home to twenty antebellum cotton fields abandoned in the late 19th century that were largely colonized by naturally regenerated slash (Pinus elliottii), loblolly (Pinus taeda), longleaf pine (Pinus palustris) and a variety of hardwood species. In the mid-20th century, many of the stands were logged and left to naturally regenerate. Currently, these stands are dense $\left(20-30 \mathrm{~m}^{2} \cdot \mathrm{ha}^{-1}\right)$, and over the past 15 years, several of these stands 
have experienced surface fires caused by lightning and patchy mortality due southern pine beetle infestation.

The hickory forest, dominated by pignut hickory, is located on a group of slight ridges ( $1-2 \mathrm{~m}$ elevation rise above the surrounding forest) in the south-central portion of the island. Pignut hickory is a natural component of maritime forest on the barrier islands of this region and was one of the Guale Indians' important food sources [8]. Carya pollen has appeared in mollusk in-fillings from cores dated from 450 years before present [15], and a preliminary pollen analysis of recent marsh cores indicates that Carya was present on or near the island 20,000 years ago (Frederick Rich, personal communication). A prior analysis of tree ages in this stand indicated that ages of hickory across all diameter classes ranged from 80 - 240 years in 2014 [12].

To identify old field boundaries, an 1867 map of the antebellum cotton fields was rectified on a recent satellite image with ARCGIS to help us identify maritime forest between the old fields. The old field boundaries were still visible on the aerial images (by differences in vegetative cover), and the location of sampling points and exclosures were randomly assigned in three groups of three throughout the hickory-dominated maritime forest. Old field boundaries were field checked during plot installation, and most of the old field boundaries could still be identified on the ground by small ditches that were dug around the fields in the 1800s.

The nine forest sampling points were permanently monumented in June 2012, and we sampled (diameter by species) all standing live and dead woody plants $>1.3 \mathrm{~m}$ height inside 0.1 ha fixed radius plots at all points. We also plotted the location of each individual tree or woody species (dead and alive) using a bearing and distance from plot center. Except for Sabal palm (Sabal palmetto) stems, none of the plots had living trees with heights < $1.3 \mathrm{~m}$. We also conducted a $100 \%$ survey of the 0.1 ha plot for hickory seedlings. We nested a 0.001 ha sampling point inside each larger plot to assess ground cover and non-hickory seedling densities. Understory plant cover (non-tree) was derived by ocular estimation of the entire 0.1 ha plot. Deer and hog exclosures were installed in July and August 2013, with one $53.5 \mathrm{~m}^{2}$ exclosure placed within $50 \mathrm{~m}$ of the permanent forest sampling points. Each exclosure was examined for tree seedlings and plant cover during installation in 2013, then re-examined in July 2014 (Figure 1).

At each site, we estimated relative frequencies, densities and dominance of all woody species. The frequency of each species was calculated by dividing the number of total plots per site by the number of plots at which the species was found. Relative frequency of each species was calculated by dividing the frequency of individual species by the sum of the frequency of all species per site and then multiplying by 100 . Density by species was found by dividing the stem density of each species by the total area of our sampling unit. The density of each species was divided by the sum of the density of each species found at each site and multiplied by 100 to find the relative density. Relative dominance was calculated by dividing the basal area per hectare for each species by the total basal area per site and then multiplying by 100 .

\subsection{Soil Sampling}

Surface soil samples $(0-10 \mathrm{~cm})$ were taken at each of the 9 plots. At each plot, 3 samples were randomly drawn and bulked for analyses. The composite soil samples were air dried, sieved through a 2-mm sieve, and then

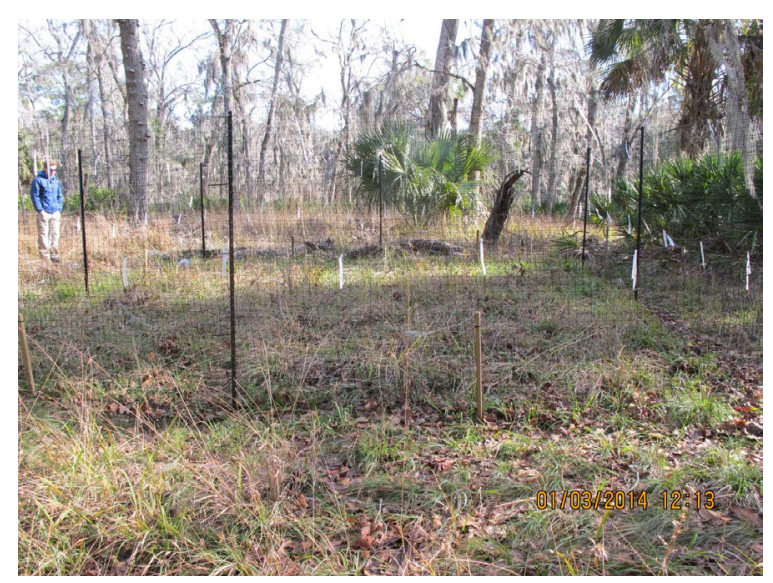

Figure 1. One of the nine animal exclosures with a view of the hickory-dominated stand during the winter of 2013. 
oven-dried at $45^{\circ} \mathrm{C}$ for 24 hours prior to chemical analyses. Soil $\mathrm{pH}$ was measured using a glass electrode in a 1:1 slurry with deionized water. Concentrations of Mehlich-3 (M-3) extractable elements (P, K, Mg and Ca) were determined using Inductively Coupled Plasma (ICP) emission spectroscopy [16]. We focused on these elements because prior work on the island indicated that these elements and soil $\mathrm{pH}$ were indicative of the presence of shell, which is a major driver of soil variability across the island [17]. Cation exchange capacity was estimated as the sum of M-3 extractable bases. Percent organic matter was measured using a Walkley-Black colorimetric procedure. All soil chemical analyses were conducted by A \& L Analytical Laboratories (Memphis, TN).

Prior to conducting parametric statistical tests, the normality of all variables was verified using a ShapiroWilk procedure. Mean forest and soil properties were compared among the three sites (three sites X three sampling units $=9$ total plots) using a one-way analysis of variance. Within subject differences in soil chemistry and for forest variables among the three sites were identified using post hoc Tukey's HSD multiple comparison procedures. Potential differences between forest variables from the 2012 and 2014 inventories were examined using a two-tailed t-test.

\section{Results}

\subsection{Surface Soils}

We detected significant differences among the three sites for $\mathrm{pH}, \mathrm{Ca}$ and CEC (Table 1). Site 1 (the most southerly set of three plots) had significantly higher values for these variables, and although evidence of shell exists throughout the hickory stand, this particular site was near a pre-historic burial mound and just north of a prehistoric Native American village which have numerous shell middens. Previous work on the island indicated that the presence of shell significantly altered surface soil $\mathrm{pH}$ and surface calcium concentrations [17]. Surface soil phosphorus $(\mathrm{P})$ concentrations were high for Spodosols across the stand, and we are uncertain why these soils would contain such high concentrations of $\mathrm{P}$.

\subsection{2 and 2014 Inventories}

Pignut hickory was present at the highest relative densities in both 2012 and 2014 (Table 2; Table 3), and we detected a decline in total basal area, hickory density and hickory basal area over the two year period (Table 4). For both years, there were no significant differences among the three sites for total basal area, numbers of live or standing dead hickory, or total numbers of live trees ( $p>0.10)$. In 2012 and 2014, hickory was ranked first in relative frequency and dominance (Table 2; Table 3). Sabal palm slightly increased in relative density in the two year period, as did American holly (Ilex opaca) (Table 2; Table 3). In both years, we inventoried all dead trees, and besides considerable hickory mortality, we found a large number of dead redbay trees (Persea borbonia), with 44 dead stems ha ${ }^{-1}$ in 2012, and 41 dead stems ha ${ }^{-1}$ in 2014.

In 2012 and 2014, saw palmetto (Serenoa repens) cover ranged from 5\% - 60\% across all nine plots, with three plots having saw palmetto coverage close to $60 \%$ and six plots having palmetto coverage of $<20 \%$. Grass cover ranged from $10 \%$ to $80 \%$ across all plots, and the six plots with the lowest palmetto cover had over $60 \%$ grass cover of the understory. In both years, all 9 plots had hickory nuts or shells in the understory. In 2012, one plot had few nuts $(<10)$, and in 2014, three plots had few nuts. The other plots in both years had nuts either in the 10 - 50 range, or $>50$.

Table 1. Mean surface soil properties $(0-10 \mathrm{~cm}$ depth) for the three sites across the dry hickory forest.

\begin{tabular}{ccc}
\hline Soil properties & Mean $( \pm \mathrm{SE})$ & ANOVA p-value \\
\hline $\mathrm{pH}$ & $5.5(0.3)$ & 0.01 \\
$\mathrm{P}\left(\mathrm{mg} \cdot \mathrm{kg}^{-1}\right)$ & $123.2(15.9)$ & 0.42 \\
$\mathrm{~K}\left(\mathrm{mg} \cdot \mathrm{kg}^{-1}\right)$ & $36.4(2.2)$ & 0.66 \\
$\mathrm{Ca}\left(\mathrm{mg} \cdot \mathrm{kg}^{-1}\right)$ & $860.3(329.5)$ & 0.01 \\
$\mathrm{Mg}\left(\mathrm{mg} \cdot \mathrm{kg}^{-1}\right)$ & $119.4(40.0)$ & 0.26 \\
$\mathrm{OM}(\%)$ & $8.1(0.9)$ & 0.22 \\
$\mathrm{CEC}(\mathrm{meq} / 100 \mathrm{~g})$ & $6.9(1.8)$ & 0.01 \\
\hline
\end{tabular}


Table 2. Relative frequency, relative dominance, and relative density for all woody species in 2012.

\begin{tabular}{cccc}
\hline Species & Relative frequency (\%) & Relative dominance (\%) & Relative density (\%) \\
\hline Carya glabra & 24.4 & 84.2 & 65.1 \\
Vaccinium arboreum & 18.9 & 0.7 & 8.9 \\
Ilex opaca & 18.9 & 6.6 & 15.3 \\
Quercus virginiana & 13.5 & 4.2 & 3.0 \\
Sabal palmetto & 8.1 & 1.1 & 4.1 \\
Pinus taeda & 5.4 & 0.8 & 1.5 \\
Symplocos tinctoria & 5.4 & 0.9 & 1.3 \\
Persea borbonia & 2.7 & 0.5 & 0.4 \\
Quercus austrina & 2.7 & 1.0 & 0.4 \\
Total & 100 & 100 & 100 \\
\hline
\end{tabular}

Table 3. Relative frequency, relative dominance, and relative density for all woody species in 2014.

\begin{tabular}{cccc}
\hline Species & Relative frequency (\%) & Relative dominance (\%) & Relative density (\%) \\
Carya glabra & 22.6 & 73.8 & 55.9 \\
Vaccinium arboreum & 20.2 & 0.9 & 12.6 \\
Ilex opaca & 17.5 & 7.5 & 17.0 \\
Persea borbonia & 9.5 & 0.3 & 2.7 \\
Quercus virginiana & 9.5 & 6.2 & 4.0 \\
Sabal palmetto & 8.3 & 9.0 & 4.9 \\
Pinus taeda & 4.8 & 0.1 & 1.8 \\
Symplocos tinctoria & 4.8 & 1.1 & 0.7 \\
Quercus austrina & 2.8 & 1.1 & 0.4 \\
Total & 100 & 100 & 100 \\
\hline
\end{tabular}

Table 4. Stem densities and basal areas for hickory and all species in the hickory stand.

\begin{tabular}{cccc}
\hline Forest property & \multicolumn{3}{c}{ Sample year (mean \pm SE) } \\
\cline { 2 - 4 } & 2012 & 2014 & t-test p-value \\
\hline Number of hickory $\left(\right.$ trees $\left.\mathrm{ha}^{-1}\right)$ & $170(21.8)$ & $139(13.9)$ & 0.3 \\
Total number of trees $\left(\mathrm{stems} \mathrm{ha}^{-1}\right)$ & $261(33.1)$ & $221(52.1)$ & 0.5 \\
Hickory basal area $\left(\mathrm{m}^{2} \cdot \mathrm{ha}^{-1}\right)$ & $13.2(1.2)$ & $11.1(0.6)$ & 0.2 \\
Total forest basal area $\left(\mathrm{m}^{2} \cdot \mathrm{ha}^{-1}\right)$ & $15.7(1.3)$ & $14.7(1.3)$ & 0.6 \\
\hline
\end{tabular}

In 2013, when the nine exclosures were built, we did not find one tree seedling in any of the exclosures. In 2014, 27 species of plants were found growing in all of the exclosures, including seven tree species that were absent in 2013. In addition, three grass species were growing in all nine plots, Piptochaetium avenaceum, Scleria triglomerata, and Chasmanthium sessiliflorum. One year after building the exclosures, pignut hickory seedling densities ranged from 0 (in one plot) to 1308 seedlings ha ${ }^{-1}$, with a forest mean of 478 seedlings ha ${ }^{-1}$. There were no significant differences among the three sites for pignut hickory seedling densities $(\mathrm{p}=0.4)$. Pinus taeda, Prunus serotina, Ilex opaca, and Quercus spp. were also found in the exclosures. 


\section{Discussion}

The hickory-dominated maritime forest on St. Catherines, with a cohort of older trees that regenerated prior to 1800 , clearly is on the decline. The total basal area in the stand has reduced from $23 \mathrm{~m}^{2} \cdot \mathrm{ha}^{-1}$ in 1996 [12] to 14.7 $\mathrm{m}^{2} \cdot \mathrm{ha}^{-1}$ in 2014. Most of the reduction in basal area has resulted from the death of pignut hickory and redbay (currently 45 and 41 dead stems ha ${ }^{-1}$, respectively). Much of the hickory mortality has corresponded to a series of drier than average years from 2000 to 2013, with five of the past 14 years having annual rainfall $20 \mathrm{~cm}$ or more below the region's average annual rainfall. Redbay, an important component of the midstory in maritime forests throughout the southeastern United States, has experienced dramatic declines throughout its range due to the invasion of the exotic ambrosia beetle and an associated fungus [18].

With the dramatic reduction of hickory in the overstory and redbay in the midstory, the maritime hickory stand currently has a very open canopy due to a lack of tree regeneration and trees in the sapling phase or midstory. Because a high amount of sunlight is now reaching the forest floor, conditions appear ideal for a new cohort of woody species and particularly hickory, to regenerate on the site [19]. Unfortunately, our results indicated that a combination of dry weather and intense browse pressure by deer had eliminated almost $100 \%$ of regenerating woody species, including almost all hickory seedlings. For example, from 1996 to 2006, Evans and Keen [12] found between 388 and 1272 hickory seedlings in their 0.6 ha plot, and they reported that higher numbers of seedlings were found among the saw palmetto compared with open grassy areas. In 2012 and 2014, we did not find any hickory or other tree seedlings in our nested 0.001 ha plots, nor did we find hickory seedlings inside the 0.1 ha plots. In 2013, we also did not find any hickory or other tree seedlings inside the areas used for our exclosures, and a random search for seedlings in the summer of 2013 by 11 individuals across 10 ha of the stand uncovered only one highly browsed hickory seedling. Thus, we hypothesized that the exceptionally dry years of 2007-2008 (84 cm of annual rainfall each year) and 2010-2011 (86 and $84 \mathrm{~cm}$ annual rainfall, respectively) resulted in a combination of lower mast production, increased mortality of mast bearing trees, and a loss of hickory and other tree seedlings through repeated browsing or death due to dessication. In the summer of 2011, environment was so dry that it was not uncommon to find recently deceased deer on roads or in open areas, which apparently showed that the mortality resulted from starvation or dehydration. Prior studies indicated that a decrease in available moisture during multiple growing seasons had a negative impact on the growth of Carya glabra and could possibly result in mortality [20] [21].

As previously mentioned, we installed the deer exclosures in the July/August 2013, and hickory mast was seen in all nine locations. In 2012, annual precipitation was near average and above average in 2013, so the recruitment success we saw in the exclosures after one year ( 478 seedlings $\mathrm{ha}^{-1}$ ) indicated that a combination of adequate surface soil moisture, protection of mast from feral hog predation and protection of seedlings from deer browse were required to recruit new hickory into the seedling and sapling phases. In future years, we will closely examine newly recruited seedlings to discover if they are regenerated from mast or if they are seedling sprouts from previously regenerated plants. Other mechanisms such as the burial of nuts by squirrels are known to be important to hickory regeneration success [22], and these animal-seed interactions warrant further study as well.

If rainfall on St. Catherines remains near average, the site conditions in the hickory-dominated stand are good for regenerating hickory and developing a younger cohort in the stand. The maintenance and establishment of Carya require increased understory light and reductions in competition from shade-tolerant species [19]. These conditions now exist on St. Catherines, and the key to recruiting a new cohort of trees is the protection of seedlings and nuts from predation during years with adequate surface soil moisture. This will require an intense effort to control the feral hog population (hog culls) and an accurate estimation of deer population densities and subsequent control of the island's deer population at levels that will allow for understory recruitment. Without control of the island's hog and deer populations, this unusual maritime forest may continue to lose its younger cohort of trees, and less palatable species such as Sabal palm may eventually dominate the stand [12]. As previously mentioned, maritime forests across the southeastern US coastline are under pressure from rising sea levels and a host of other anthropogenic stresses. There is great conservation value in taking measures to protect and maintain all remaining maritime forests, and particularly those maritime forests with an unusual assemblage of dominant species such as the dry hickory forest on St. Catherines Island.

\section{Acknowledgements}

The authors would like to thank two anonymous reviewers for making contributions to the paper, as well as the 
St. Catherines Island Foundation for logistical support on the island. Sewanee's Environmental Studies Program and Forestry and Geology Department provided stipends for the student authors on this paper, which enabled them to conduct fieldwork on the island in 2012 and 2014.

\section{References}

[1] Bellis, V.J. (1995) Ecology of Maritime Forests of the Southern Atlantic Coast: A Community Profile. National Biological Service, Washington DC.

[2] Hayden, B.P., Dueser, D., Callahan, J.T. and Shugart, H.H. (1991) Long-Term Research at the Virginia Coast Reserve. BioScience, 41, 310-318. http://dx.doi.org/10.2307/1311584

[3] Bratton, S.P. and Miller, S.G. (1994) Historic Field Systems in the Structure of Maritime Oak Forests, Cumberland Island National Seashore, Georgia. Bulletin of the Torrey Botanical Club, 12, 1-12. http://dx.doi.org/10.2307/2996879

[4] Sherrill, B.L., Snider, A.G. and DePerno, C.S. (2010) White-Tailed Deer on a Barrier Island: Implications for Preserving an Ecologically Important Maritime Forest. Proceedings Annual Conference Southeastern Associated Fish and Wildlife Agencies, 64, 38-43.

[5] Wood, V.S. (1981) Liveoaking, Southern Timber for Tall Ships. Northeastern University Press, Boston.

[6] Dolan, R. and Lins, J. (1986) The Outer Banks of North Carolina. USA Geologic Survey Professional Paper, 1177-B, Reston .

[7] Williams, L.J. and Hughes J.D. (2011) Updating the Hydrologic Framework and Underlying Hydrologic Databases That Are Being Used for Future Modeling Efforts. South Florida Hydrologic Society. http://sfhs.fiu.edu/Contents/Presentations/SFHS 2011 5 18.pdf

[8] Thomas, D.H. (2008) Native American Landscapes of St. Catherines Island, Georgia. I. The Theoretical Framework. American Museum of Natural History, Anthropological Papers, Number 88, New York.

[9] Linsley, D., Bishop, G.A. and Rollins, H.B. (2008) Stratigraphy and geologic evolution of St. Catherines Island. American Museum of Natural History, Anthropological Papers, Vol. 88, 26-41.

[10] Smalley, G. (1990) Carya glabra (Mill.) Sweet Pignut Hickory. Silvics of North America, Washington DC, $198-204$.

[11] NatureServe (2014) Nature Serve Explorer: An Online Encyclopedia of Life. Version 7.1., NatureServe, Arlington. http://explorer.natureserve.org

[12] Evans, J.P. and Keen, E.M. (2013) Regeneration Failure in a Remnant Stand of Pignut Hickory (Carya glabra) on a Protected Barrier Island in Georgia, USA. Natural Areas Journal, 33, 171-176. http://dx.doi.org/10.3375/043.033.0207

[13] USDA Natural Resource Conservation Service (2014) Published Soil Surveys for Georgia. http://www.nrcs.usda.gov/wps/portal/nrcs/surveylist/soils/survey/state/?stateId=GA

[14] Georgia Coastal Systems LTER (2014) UGA Marine Institute Climate Monitoring. http://gce-lter.marsci.uga.edu/portal/ugami_climate.htm

[15] Rich, F.J., Newsom, L., Meyer, B. and Vance, K. (2014) Radiocarbon Dates and the Genesis of Phytogenic Near-Shore Sediments on St. Catherines Island, Georgia, USA. Environmental Earth Sciences, 72, 2985-2997. http://dx.doi.org/10.1007/s12665-014-3203-Z

[16] Ziadi, N. and Tran, T.S. (2008) Mehlich-3 Extractable Elements. In: Carter, M.R. and Gregorich, E.G., Eds., Soil Sampling and Methods of Analysis, CRC Press, Boca Raton, 81-88.

[17] Smith, C.K. and McGrath, D.A. (2011) The Alteration of Soil Chemistry through Shell Desposition on a Georgia (USA) Barrier Island. Journal of Coastal Research, 27, 103-109. http://dx.doi.org/10.2112/JCOASTRES-D-09-00086.1

[18] Spiegel, K.S. and Leege, M.L. (2013) Impacts of Laurel Wilt Disease on Redbay (Persea borbonia (L.) Spreng.) Population Structure and Forest Communities in the Coastal Plain of Georgia, USA. Biology Invasions, 15, 2467-2487. http://dx.doi.org/10.1007/s10530-013-0467-2

[19] Cowden, M.M., Hart, J.L. and Buchanan, M.L. (2014) Canopy Accession Strategies and Climate Responses for Three Carya Species Common in the Eastern Deciduous Forest. Trees, 29, 223-235. http://dx.doi.org/10.1007/s00468-013-0944-3

[20] Orwig, D.A. and Abrams, M.D. (1997) Variation in Radial Growth Responses to Drought among Species, Site, and Canopy Strata. Trees, 11, 474-484. http://dx.doi.org/10.1007/s004680050110

[21] Abrams, M.D., Ruffner, C.M. and Morgan, T.A. (1998) Tree-Ring Responses to Drought across Species and Contrasting Sites in the Ridge and Valley of Central Pennsylvania. Forest Science, 44, 550-558.

[22] Sork, V.L. (1983) Distribution of Pignut Hickory (Carya glabra) along a Forest to Edge Transect, and Factors Affecting Seedling Recruitment. Bulletin of the Torrey Botanical Club, 110, 494-506. http://dx.doi.org/10.2307/2996284 
Scientific Research Publishing (SCIRP) is one of the largest Open Access journal publishers. It is currently publishing more than 200 open access, online, peer-reviewed journals covering a wide range of academic disciplines. SCIRP serves the worldwide academic communities and contributes to the progress and application of science with its publication.

Other selected journals from SCIRP are listed as below. Submit your manuscript to us via either submit@scirp.org or Online Submission Portal.
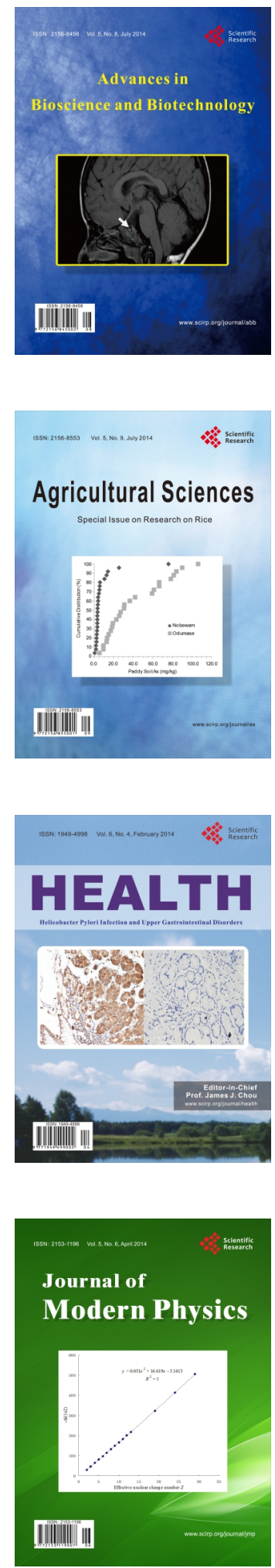
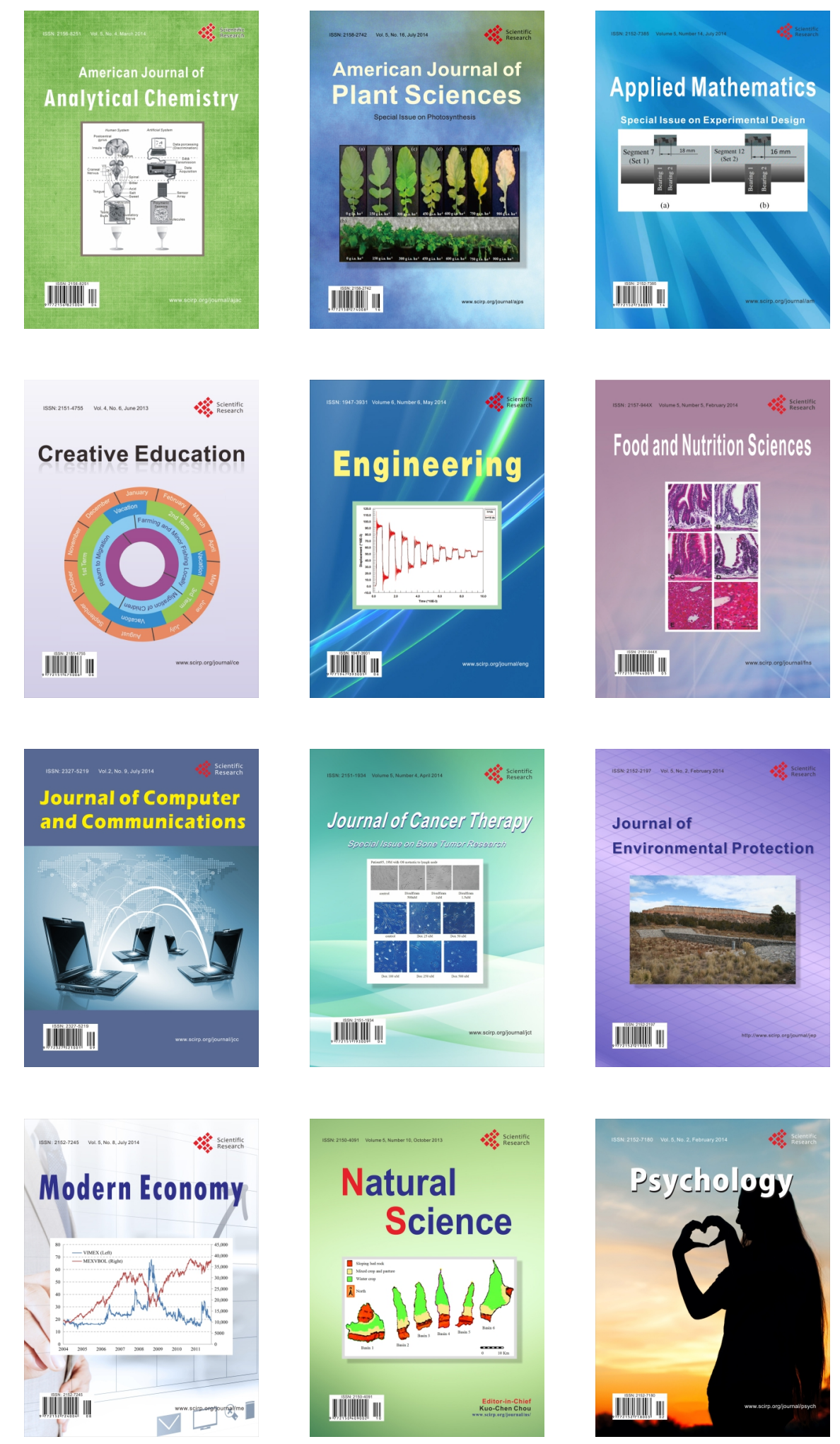